\title{
ISRAEL: FINDING THE LEVANT WITHIN THE MEDITERRANEAN
}

\author{
Rachel S. Harris
}

Alexandra Nocke. The Place of the Mediterranean in Modern Israeli Identity. Brill 2010, Cloth \$70. ISBN 9789004173248

Amy Horowitz. Mediterranean Israeli Music and the Politics of the Aesthetic. Detroit: Wayne State University Press, 2010. Paper \$29.95. ISBN 9780814334652.

Karen Grumberg. Place and Ideology in Contemporary Hebrew Literature. Syracuse: Syracuse University Press, 2011. Cloth \$39.95. ISBN 9780815632597.

Zionism as a national movement sought to unite a dispersed people under a single conception of political sovereignty, with shared symbols of flag, anthem and language. Irrespective of where Jews had found a home during 2500 years of (at least symbolic) nomadic wandering, as guests in other lands, they would now return to their ancient homeland. For such an enterprise to succeed, a degree of homogenisation was required, where differences would be erased in favour of shared commonalities. These universalised conceptions for the new Jew were debated, explored, and decided upon by the leaders of the movement whose ideas were shaped by European theories of nationalism. From the beginning of the Zionist movement in the late nineteenth century and its territorialisation in Palestine, Jews faced the challenge of looking towards Europe socially and intellectually, while simultaneously attempting to situate themselves economically and physically within the landscape of the Middle East. This hybridity can be seen in a self-portrait by Shimon Korbman, a photographer working in Tel Aviv in the 1920s:

Sitting on a small stool on the sand next to the sea, he faces the camera, dressed in his white tropical summer suit, an Arabic water pipe - Nargila -in his hand. In this image the longing that Korbman shared with many other immigrants at the time becomes apparent: to preserve aspects of a Western cultural heritage, but at the same time to display the behavior of a local and blend in in order to feel at home in the old-new land. (Nocke, 9)

There is both a sense of harmony in this picture; a man sitting near the sea, and the sense of conflict; his dress, seat and manners are incongruent with the landscape in which he wants to belong. This constant tension that Alexandra Nocke describes through a single image, in many ways lies at the heart of Israeli identity as it has developed over the course of the twentieth century and into the early years of the twenty-first. "The two poles within Israeli culture - to merge into the East and become part of it on the one hand, while simultaneously remaining distinct from it on the other - are still at the center of discussions about the concept of Israeliness." (Nocke, 19)

This European balancing act could only be maintained by careful processes of selection and rejection; wear the suit but hold the nargila, sit by the sea, but upon a stool. Korbman faces the 
camera with the sea to our right, posed with his back to Jaffa, which in the rhetoric of early Tel Aviv's construction, demonstrates his rejection of the Arab world for the forward looking future of the new European-style city just out of sight. This particularised form of Zionism with its romantic attachment to the indigenous landscape and people, while maintaining an attitude of colonial superiority, was sustained during the 1930s and 1940s. But massive waves of migration in the 1950s by Jews of Arab lands, threatened to destroy the carefully constructed equilibrium. In the newly formed State of Israel, the delicate adoption of selective facets of Middle Eastern culture as decoration for the principally European ideas, threatened to be submerged in the new culture Jews carried with them from a perceived 'East'. Though half of Israel's Jewish population is descended from these 'Eastern' Jews, it would take decades before they would gain sufficiently significant social and cultural status to upend the hegemonic dominance of 'Western' Jews. In recent years, a return to discussions of Levantine identity, with its associations of plurality, multiculturalism and acceptance have been embraced as attempts to rethink Israel's identity with both the East and West have come to the fore.

Underpinning contemporary conceptions of Levantinism are Fernand Braudel's ideas about la Méditerranée. Though he saw multiple overlapping notions of Mediterranean culture and commerce, rather than a singly defined interpretation, he highlighted the significance of regional cultures that cross traditional national boundaries. In his work on the Mediterranean, he demonstrated a shared economic and cultural attitude in the late Medieval period that reflected similarities between countries surrounding the sea. Glancing back at the poly-ethnic empires of an early period, he concluded that a rigid adherence to traditional boundaries which characterised modern nationalisms could be superseded in a shared identity that reflected regional commonalities in agricultural habits, trade, urban living, education, knowledge, monotheistic ideas - and which were shaped by temperament, food and climate. ${ }^{1}$ The close geographical proximity of Southern Europe to North Africa and the Eastern Mediterranean as well as some shared historical experiences further linked these regions. While these earlier forms of conquest and colonialism (Ottomans, the spread of Islam) had a profound impact on shaping Mediterranean development, theorists turned rather to the later influences of European colonial control (especially France and Britain) to provide an explanation for the socio-cultural hybridity of the Middle East. They argued that under the influences of colonial control, European languages and Western ideas penetrated deeply among the cultural elites, evident in movements such as Lebanese Phoenicianism which highlighted a Levantine identity that celebrated the polyphony of the region's religious and ethnic populations. Arab, Persian, Turk, Babylonian, Assyrian and Egyptian, Muslim, Jew and Christian, spoke to a cosmopolitanism which crossed boundaries, disrupting modern pan-Arabism or individualised nationalisms. Hence, the Levant was, in this framing, the cradle of all civilisation not a barbarous and uncultured terrain but the bridge between the Far East and the West, which had held on to culture and knowledge at precisely the moment in time when Europe had abandoned it.

Levantinism could represent fluidity; identity unbounded, with no fixed location, language or singular identity. Gil Hochberg has identified Levantinism as "a state of performing culture: 'going through the external forms of culture, without actually possessing them'." ' It is a way to

\footnotetext{
${ }^{1}$ Fernand Braudel, Memory and the Mediterranean (New York: Alfred Knopf, 2001), 96.

2 Gil Hochberg "“Permanent Immigration”: Jacqueline Kahanoff, Ronit Matalon, and the Impetus of Levantinism” Boundary 2 Vol. 31, No. 2, Summer 2004, 219-243, 220-221.
} 
engage with culture, even when not entirely assimilated. The refusal to be contained, to live in multiple worlds simultaneously, was the strength of Levantinism for those who advocated it, and precisely its source of critique for those who rejected it and saw in it a line of despised "cross breeds" 3 . Albert Hourani claimed that to be Levantine "is to belong to no community and to possess nothing of one's own"4. Levantinism's refusal to conform, with its knowing rejection of constraints and boundaries, suggested subversion, a mode that has been increasingly embraced deliberately within a cultural and political discourse rejecting ideological purism.

Israel, which had been determined to create an untainted new cultural identity, was at pains to reject Levantine associations. Nonetheless, dramatic changes within Israeli society have led to its resurgence in recent years creating a new respect for Levantinism. Much of this recent embrace has been disguised under a new camouflaging adjective Yam Tichoni (which may translate as 'of the Mediterranean Sea', but is comparable to the use of Braudel's Mediterranean and its adverbial form Yam Tichoniut 'Mediterranean-ness'). Three recent books explore Israel's changing relationship with its Levantine identity. Though they vary in fields (ethnography, ethnomusicology, literature) these works share approaches that look at the historic transformation of these ideas, the primacy of culture in shaping them, and the importance of Jacqueline Kahanoff's writings in the late 1950s and 1960s as a foundation for today's conceptions of Levantinism.

Drawn from the French, the term Levant referred to the East, and referred both to the persons and the landscapes of an unclearly defined territory of the Eastern Mediterranean. Levantine became synonymous with the term Oriental as used within British and French colonial discourse. An underlying pejorative implication existed within the expression of things being Levantine, which suggested "a state of cultural impurity, a failed attempt on the side of the colonized to imitate the way of the West" with the implications that persons who were Levantine lacked "any real culture or spiritual stability" . As scholars have claimed: "being a Levantine means being everything at once and nothing in particular" (Nocke 183). Within Israel, Hebrew too adopted this term along with the implied fear of Levantinisation, being consumed by the cultural and social forces of Jews from the Arab world and abandoning the cultural aspirations of European Jews.

Analogously, the term Mizrachi (Eastern) with a similar etymological and colonialist framing, came to be used in Israel to describe the Jew of Arab descent. The religious term, Sephardi, which had come to imply one specific type of Jew (those whose ancestors had fled from Spain around the fifteenth century migrating around the Mediterranean), and had aristocratic connotations within certain circles, was side-lined. Instead the deleterious Mizrachi was established in opposition to the valuable Ashkenazi, a no less fraught term suggesting Jews with European origins.

\footnotetext{
3 Jacqueline Kahanoff in "Israel: Ambivalent Levantine" Deborah Starr and Sasson Somekh, Mongrels or Marvels: The Levantine Writings of Jacqueline Shohet Kahanoff, (Stanford, CA.: Stanford University Press, 2011), 211

${ }^{4}$ Albert Hourani, Syria and Lebanon: A Political Essay (London: Oxford University Press, 1946), 70-71.

${ }^{5}$ Gil Hochberg “"Permanent Immigration”: Jacqueline Kahanoff, Ronit Matalon and the Impetus of Levantinism," Boundary 2 (Duke University Press) 31, no. 2 (2004) 219-43.

${ }^{6}$ Gil Hochberg "“Permanent Immigration” 221
} 
Using the terms Oriental, Mizrachi or Levantine is problematic on multiple levels. Along with setting up a hierarchical power relationship, "[s]uch broad categories obscure the diversity of those who emigrated from more than one hundred countries and comprise dozens of ethnic subgoups" (Horowitz p11). Through these terms the diverse identities were streamlined into a single marker "with all the unpleasant connotations [that] these words include: corruption, dictatorship, backwardness, poverty, and retrogression.”(Grumberg, 9) The ethnic and cultural segregation of many Jewish immigrants from Arab lands in the 1950s and 1960s into new border towns, often in newly conquered and undeveloped territories far from the county's economic and social centre, compounded negative attitudes towards Mizrachim within Israel. In time, levantine became a euphemism for poverty and crime. "Already in 1955, for example, a report on the development town Beit Shean (whose residents were mostly from Iran and Iraq) asserted that it had become "a backward Levantine city"; an openly racist charge equating the residents' Eastern cultural background with the town's failure. This assertion was made despite the acknowledgement that it was the authorities' failure to invest in infrastructure, education, culture and vocational institutions that impeded the town's progress" (Grumberg, 63)

The marginalisation of Mizrachi culture within Israeli society had several effects. While it remained barely visible on the surface during Israel's formative years, this public exclusion forced Mizrachi culture underground. As a result, the social, cultural and economic experiences of Jews from Arab lands, Greece, Turkey, India and Iran led to new kinds of engagements with one another. At the same time, these Mizrachi Jews were able to engage and negotiate with Arabs in the surrounding areas in ways which were inaccessible and unimaginable for Ashkenazi Jews. These dynamics forcibly created an incubator of social and cultural development, whose fermentation led to an eruption in the late 1970s.

Determined to reclaim the term Levantine from its negative association in Israel, and embrace her contemporaries in Lebanon and Egypt, Jacqueline (Shohet) Kahanoff (1917-1979) an Egyptian-Jewish novelist, journalist, essayist and public intellectual, attacked the attempted homogenisation of Israeli society and looked outwards at a national and international plurality which she believed could be adopted within Israel. Her father's family hailed from Iraq and her mother's family came from Tunisia, and she was born and raised in Egypt during a period of tolerant intellectual co-existence, and educated within a private, elite, French school system. Examining the cultural past of her childhood provided the model for a diverse (and accepting) new order, which she presented in the cycle of essays "A Generation of Levantines" published in 1959. ${ }^{7}$ Having lived in San Francisco, New York, London and Paris before settling in Israel she brought a sophisticated cosmopolitan eye to her writings about the new immigrants arriving in Israel from the Arab world. At a time when writers were looking inwards at the relationship between the individual and the state, her beliefs ran counter to Israeli ideals:

[she] believed that it was only natural for people to understand each other even though they spoke different languages, for them to have different names-Greek,

\footnotetext{
${ }^{7}$ Deborah Starr and Sasson Somekh, Mongrels or Marvels: The Levantine Writings of Jacqueline Shohet Kahanoff, (Stanford, CA.: Stanford University Press, 2011.)
} 


\section{Muslim, Syrian, Jewish, Christian, Arab, Italian, Tunisian, Armenian-and at the same time be similar to each other. ${ }^{8}$}

Kahanoff, the founding mother of Levantine thought in Israel, brought into an Israeli context the intellectual discussion raging across the Arab world among her Arabophone and Francophone contemporaries and elders in Alexandria and elsewhere, such as Taha Husayn, Michel Chiha, Charles Corm, and Constantine Cavafy, whose works she knew well. ${ }^{9}$ Chiha and Corm were Lebanese, and wrote exclusively in French, which she read. Husayn and Cavafy were Egyptian, and wrote respectively in Arabic and Greek, which she also read, but with which she was arguably not as comfortable as French. Her reflections on the particularity of Levantiniut (Israeli Levantinism) underpin many of the attitudes explored in the three new scholarly texts considered in this essay.

Reflecting on the decline in tolerance and interaction, in "Israel: Ambivalent Levantine" she claimed that "This old tolerance has given way to the modern passion for a monolithic unity, or for a type of unity which excludes all variation"10. Her proposed model for a local mode of Levantinism argued that the Mizrachi Jew was well placed to be the negotiator of culture between the Arab and Western worlds. Kahanoff "promoted an open, pluralistic society in the Levant and saw Israel as an integral part of the Mediterranean and the Levantine world. She introduced her model of Levantiniut and thereby shifted the colonialist connotations of the term Levant to a new cultural position" (Nocke 183). Rejecting the Zionist constraints of home versus homeland, and monolingualism (Hebrew) for the polylingual frameworks (English, French, Arabic) in which she was raised, she argued that Levantines were people who did not fit into a single place, but instead, belonged among other Levantines wherever they may be. In embracing Levantiniut she appeared to reject all that Israel stood for, but her ideology was a new way of framing Zionism, aimed at Israel's survival: "Kahanoff became convinced that Israel would never find peace until it recognized that it was in the Middle East." 11

Her ideology emphasized the region's rich cultural heritage and sought to present it as a microcosm of multiculturalism in a modern world newly fascinated by such ideas. The influence of such thinking can be seen in a 1936 commercial enterprise called the Levant Fair. "The organizers of the exhibition, which had a flying camel as its logo, used the name Levant Fair intentionally, as they wanted to revive a tradition of trade and exchange in the region. In the title Levant Fair the negative undertone was missing and the constructive qualities of the region were evoked: the Levant as an area of exchange, connectedness, and reciprocal contacts."(Nocke 182)

Though she wrote in English and French, most of Kahanoff's writings were published in Hebrew translation. Until recently, her writing was little known outside select literary circles, or outside Israel (though during her lifetime she had been a prolific journalist, which provided her widest audience). A popular public intellectual among the cultural elite in Israel, she was championed by Aharon Amir who translated and published her cycle of Levantine essays in the

\footnotetext{
${ }^{8}$ Alexandra Nocke, The Place of the Mediterranean in Modern Israeli Identity, (Leiden and Boston: Brill, 2009, ) 221.

${ }^{9}$ For more on the Egyptian and Lebanese antecedents, see for instance Asher Kaufman's Reviving Phoenicia; The Search for Identity in Lebanon (London: I.B. Tauris, 2004), and Franck Salameh's Language Memory and Identity in the Middle East; The Case for Lebanon (Lanham, MD: Lexington Books, 2010).

10 Jacqueline Kahanoff in "Israel: Ambivalent Levantine", 211.

${ }^{11}$ David Green "Levantism finds its place in modern Israel” Ha'aretz 25.08.11
} 
literary journal Keshet. Aharon Amir emerged out of the Canaanite movement, the only serious counter voice to traditional Zionism in the 1950s. This movement called on Arabs and Jews to search for the connection of their shared Canaanite past and reject modern religion. Thus, in some ways, Israeli concepts of Levantinism emerged from a conversation in which Jews and Arabs shared identity, and therefore culture, values, and the possibility of mutual discourse. Though Canaanism was never to gain political strength, it had a profound impact on cultural producers, artists and writers, fostering creative talent over three generations. Criticism of Kahanoff has focused on the incongruity and blindness of her notions of Levantine in which the Mizrachi/Ashkenazi divide is well documented, while the Jew/Arab divide is ignored. The very colonialist discourse that she critiqued in a Jewish context, she reinforced in a Palestinian one. Preferring French and English, accused of not speaking or reading literary Arabic despite her obvious Middle Eastern heritage, and dismissing Arabs as workers incapable of negotiation and advancement, her theories reveal naiveté, elitism and racism. Despite the major significance of her ideas, these flaws have led to increasing denunciation among contemporary scholars, a critique that is evident in Ronit Matalon's engagement with Kahanoff, explored in Grumberg's work.

In many ways, the conversation about Levantinism was marginalised in Israel precisely because it stood in opposition to the traditional hegemonic structures within the emerging state which looked towards Europe and not the East as the source of aspirational life and culture. The East, by comparison, was ridiculed and rejected with the Orientalist view of the European migrants who fetishized aspects of the Orient, but did not accept the Levant on equal terms. Though gestures were made to integrate local culture into the Zionist discourse, these were often nothing more than symbolic and were quickly rejected by later movements within the Yishuv (the Jewish settlement in Palestine) and the early years of the state. Examples of this phenomenon are particularly evident in the material arts. Architecture in the early years of Tel Aviv (1909-1920s) explored an 'eclectic style' which embraced the thin windows and arches of Arab dwellings, which gave way to Art Deco and then Bauhaus socialist housing styles from the late 1920s onwards. As Nocke shows these new styles were profoundly influenced by the training, ideology and tastes of newly migrated European architects. Horowitz describes this phenomena particularly in reference to music, where: "As Middle Eastern and North African immigrant musicians made music out of their encounter, they began to forge a counter sound track to the established repertoire, whose European Israeli creators in turn appropriated select elements of the new hybrid music while roundly rejecting the musical form itself." (Horowitz 3)

As musical attitudes have changed, and Mizrachi culture has gained increasing prominence in music, art, literature and film, Kahanoff's ideas can be found within the reclamation of Levantine identity. Yet the term could never be entirely stripped of its negative connotations, even as social revolutions were increasingly attracted to cultural difference both within Europe and Israel. For a long time, Levantinism was coded language for Mizrachi, implying low class and hence excluded culture. The infiltration of Mizrachi culture into the Israeli (Ashkenazi) mainstream during the 1980s, and its ascension can be seen alongside Mizrachi reclamation of identity through power struggles (black panthers, Shas movement) and in some sense the whitening of Mizrachi identity in order to conform to social trends. These transformations occurred at precisely the time in Israeli (and Western) culture when an interest in the exotic and foreign has become fashionable. In Israel, the clearest articulation of this modification can be seen in the recent substitution of the term 'Mediterranean' in the place of Levantine - thereby speaking to 
the West as much as to an Eastern identity, and in doing so evoking Braudel's theories of Mediterraneanism.

In an attempt to define the hybrid space that Israel occupied culturally and geographically between East and West, the term 'Mediterranean' found increasing currency within cultural discourse. Though it spoke to the warmth, vibrancy and exoticism of the East, it also suggested a shared relationship with the West (Spain, France, Italy and Greece) which had been more traditionally used in descriptions of what Nocke refers to as Yam Tikhoniut (Mediterranean Seaness). Its popularity hid the subtle laundering of the term Levantine, leading to an overall 'whitening' in Israeli culture of precisely that which had been threatening in its ethnically Arab and Eastern form.

The term Mizrahiut implies, according to the prevailing sentiment among Mizrahim themselves, a position of ethnicity. The notion of Yam Tikhoniut resurfaced in the context of polishing up the Mizrahi image. Over the years, Mizrahi culture was forced into the inferior position of 'ethnic' culture vis-à-vis 'elite' culture. The label of ethnicity is often seen as stigmatizing, whereas the term Yam Tikhoniut carries fewer derogatory connotations: it is less oriental, more European, and overlaid with the Western images of 'classic[al]' culture. (Nocke 167)

Nocke's book focuses on this transformation of the term Mediterranean and its increasing usage and acceptance within Israeli society. Her ethnographic study explicates the changing attitudes to the Israeli sense of identity - moving beyond the historic boundaries of East and West to see the increasing cultural fusion that has occurred. Her persuasive examples are drawn from material and visual culture, including advertising, academia, art and literature. Furthermore, she places this growing attitude towards the term on the larger stage of changes in European cultural tastes, observing at both a general level, and at the most nuanced micro-level (such as food) the extent to which, even within this framework, cultural differences exist in the portrayal and representation of the Mediterranean.

The Place of the Mediterranean in Modern Israeli Identity provides a dialogue between internal notions of culture and Israeli attitudes to the local, and the relationship between Israel and the lands around the Mediterranean in an international and unbounded sense. The chapters are divided to demonstrate the historical transformation that has taken place within Israeli attitudes providing a detailed analysis within each historical period including a discussion of terms, trends and culture. This is a seminal work in its consideration of Israel within regional affiliations that look beyond the binaries of East and West, to forms of regional alliances that challenge previously well-established and well-trodden divisions. Painstakingly researched, this book is further enriched by the many images, and particularly the colour plates which appear at the end.

The rebranding of the Levant can be seen in the use of the term 'Mediterranean' in the titles of both Nocke's and Horowitz's books. Yet, even here there is some diversity in meaning. For Nocke it is an expression of unification with a world beyond Israel's boundaries, for Horowitz it is, in many ways, a synonym for Mizrachi, an inward term exploring Israel's own relationship to the heritage of its population. As Nocke rightly points out: 
there is no consensus on defining the crucial terms in this discussion, and expressions like Mizrahiut, Orientalism, Arabness, Mediterraneanism, or Levantinism are sometimes combined or even confused with each other. The only constant factor is that the Mediterranean concept is still in its formative period. (Nocke 2) (italics hers).

Thus these terms, like the very questions of labelling, reveal the difficulties in separating out the strands of the Levantine within Israeli identity. Horowitz and Grumberg both take on this challenge in different ways. Grumberg examines the aspects of place that are constructed through ideology, returning us to the questions of home or homeland that featured in Kahanoff's writing, and have come to occupy current literary explorations of Levantinism, which I will return to in a moment. Horowitz in her exploration of 'Mediterranean' Israeli music looks at the counter-culture within the Israeli music industry 1975-1995 from an ethnomusicology standpoint. She explores not only the producers and artists of the music, but its reception in Israeli culture and the transformation of its position on the margins, to its increasing acceptance within the mainstream. Once, the recordings of this kind of music could only be found produced in low budget, cottage industry recordings. This music was replicated due to the innovations of the tape deck, and sold on market stalls around the Tel Aviv bus station giving it the negative nicknames 'Bus Station music' or 'Tape music' among the cultural elites. Today, along with the growth of world music in general, this has become a multi-billion dollar industry. This music incorporates not just traditional tunes from Greece, Turkey and north Africa, sometimes with Arabic words, and sometimes with Hebrew; but also plays with secular and religious texts in its lyrics; as well as musical innovations in the new areas of 'Oriental Rock' and 'Oriental Metal' which have evolved since the 1980s.

In her opening chapters Horowitz traces this evolution in Mediterranean music through its more general history, exploring types of music, the history of the industry and its economic development using interviews with artists, producers and family members of the more famous practitioners, newspaper clippings, field observations and her own extensive collection of tapes from her research trips. The later chapters of the book deal with two of the most celebrated Mizrachi artists, whose fame was not only celebrated within traditional Mediterranean musical circles, but crossed over into the mainstream. In chapters 4 and 5 she looks at Zohar Argov. This musical legend, born in a Yemenite Israeli home, embodies many of the stereotypes associated with Levantine culture - impoverished, criminal, ill-educated, and associated with drugs and violence, yet his musical talent allowed him to transcend many of the social restrictions of his circumstances. Horowitz cleverly explores his life and music using historical sources, examining musical innovations and interviewing surviving family and friends. She then explores the construction of his legend following his death at thirty-two, with its selective treatment of his history whereby his well-documented drug usage is presented as a warning for others, that crosses ethnic, racial and economic boundaries, while his conviction for rape is generally sidelined. Zohar Argov erupted into the mainstream in the late 1970s, forging a new path for Mizrachi culture within public spheres, and by the 1990s Israel cultural trends had transformed dramatically and eagerly consumed all that the Mediterannean could offer. In chapter 6, which examines the career of Zehava Ben, Horowitz demonstrates the ascendency of not just a JewishArab hybrid culture, but the annihilation of traditional musical boundaries in Israel. Increasingly, Israelis were willing to hear and engage with Arab culture. Ben was not simply imitating this culture in its purest form with her renditions of authentic Arab music, but, as the daughter of a 
Moroccan musician, was performing legitimately within a tradition that had suffered marginalisation and relative concealment for decades. She gained prominence within the mainstream Israeli community, was beloved in the traditional Mizrachi community and also had an audience among Palestinians and Israeli Palestinians. By performing a range of traditional pieces as well as music that suggested a synthesis of East and west, she became the face of Mediterranean music in Israel.

Arab music is part of the sound track of modern Israel. Ben's covers of Umm Kulthum enabled Arab music to waft out of the circumscribed ghettos where media efforts at containment had proved ineffective. Regardless of critical evaluations, whether by academics or journalists, about what belongs where or to whom, the music already had seeped across the borders and it was too late to send it back "home," wherever that was. Mediterranean Israeli music relocated the other in the self, them in us. (Horowitz, 154)

This dissolution of boundaries, Ben's border-crossing, and the disputing territories of Horowitz's final chapter dissolve the "inherited binaries" (155) that had characterised Israeli attitudes to Mizrachiut, demonstrating the Levantine destabilization that cannot be contained.

Throughout the book Horowitz is aware that she is writing for a mixed readership, addressing an audience who may not be educated in music, musical forms, or the characteristics that are particular to Mediterranean music. She explains these aspects carefully with pronounced clarity, as well as providing contextual information about the cultural and historical forces at play for Mizrachi Jews within Israel. The final sections of the book which accompany the CD (with 19 illustrative tracks) offer the lyrics in transliteration and translation, as well as information about each song in terms of musical style, instruments, language, and other pertinent information. These additions are extremely useful in understanding the musical ideas explained within the text, furthering the importance of this text for those outside her field. Certain chapters are accessible to undergraduates, and as a teaching tool this book is incomparable to anything available in English.

Karen Grumberg's Place and Ideology in Contemporary Hebrew Literature differs from Nocke and Horowitz by not addressing the issue of Mediterranean or Levantine culture as a specific manifestation directly. She explores the treatment of spaces in Israeli literature, and the ways in which these frame ideas about the state's attitudes towards space and place in order to construct a national identity. In time these positions are challenged in multitudinous ways by writers who reject the mainstream. However it is precisely her situating of Amos Oz, who rose to prominence during the 1960s and 1970s, alongside the Arab-Israeli writer and journalist Sayed Kashua who began writing in the 2000s, and novelist and academic Ronit Matalon born to Egyptian-Jewish parents, who emerged on the Israeli literary scene during the 1990s, that reveals the extent to which Levantine culture has dislodged the central historic narratives and replaced it with the margins it sought to exclude. Amos Oz, second only to the Nobel Prize winning S Y Agnon, in the Israeli canon, signifies the Israeli establishment, from its hegemonic control of Israeli politics and culture through most of the history of the State of Israel. Known as part of the 'New Wave' or 'Dor Ba'Aretz' (the generation of the State) his role among Israel's most well respected and venerated public intellectuals is incontestable. Thus, by situating Kashua an Arab with Israeli citizenship (she refers to as a Palestinian Israeli) and Matalon, a member of the Forum for 
Mediterranean Culture at the Van Leer Institute, alongside Oz, Grumberg demonstrates the central role that Levantine culture has acquired within the Israeli discourse.

Each of Grumberg's five chapters considers a different author's reaction to the construction of ideological spaces. Along with Kashua and Matalon, she also explores the bad-girl of Israeli prose, Orly Castel-Bloom in her fracturing of Israeli spaces, and the breakdown of inside/outside, public/private which she describes as "related to a project of appropriating and demarcating purportedly unclaimed, undeveloped, or wild space and transforming it through manual labor to a place that is owned, developed, and 'civilized'." (Grumberg, 79). Her chapter on Yoel Hoffman, whose prose has been influenced by Japanese culture, examines the failure of Zionism to account for the diverse experiences of its inhabitants, and his expressions of this attempt to reclaim place through language. These writers convey the critique taking place in literature that was part of a more general pattern of changing Israeli responses. Increasing Americanisation and public protests to the [first] Lebanon War "were some of the factors that converged to create an atmosphere of greater openness, a loosening of ideological structures, and a readiness to face criticism" ... "Thus, novels, poetry, and short stories by Mizrahi authors, women, Israeli Palestinians, and others began to seep into public consciousness. Their writing challenged the perception, propagated in part by the established literary canon, of a more or less homogeneous Israeli identity, offering instead a postmodern conception of a plurality of widely varied experiences of Israel." (Grumberg, 78.) Grumberg's treatment of Kashua and Matalon, offers an examination of the place of the Levantine within the current Israeli literary and cultural scene.

Sayed Kashua's novels explore issues of passing, hybridity and competing identification. His writing conjures up the sense of at once belonging everywhere and nowhere that, historically, had been part of the Jew's Levantine identity. Forced into a spatial hierarchy by the presence of roadblocks which become "the defining geographical metaphor of the interstitial experience of Israeli Palestinians, who must choose, as they approach the roadblock, whether to reveal their Arab identity or conceal it and attempt to assume a Jewish Israeli one." (Grumberg 136.) Kashua offers characters in Dancing Arabs, Let It Be Morning (and within his television series Arab Labor), who exist as bilingual in Hebrew and Arabic, constantly negotiating the limitations of East and West, and functioning as the cultural bridge between these polar locals. The archetypal Levantine, able to cross-boundaries and confuse binary definitions, Kashua's characters have a historic identity that has been disrupted by the present, leading to a constant oscillation between competing and conflicting expectations. His characters remain highly educated, often intellectuals, who are satirised for their elitism, naiveté and racism. His writing rejects what he presents as the empty rhetoric and vacuous ostentatious bravado of Arab life, and the paranoid, aggressive, petty and culturally blind Israelis. However, rather than seeing Levantinism as the solution he ridicules the possibility of finding an answer in cultural fusion, instead demonstrating repeatedly the isolation that the hero who adopts this position, faces. Thus Kashua skilfully dislocates Kahanoff's ideas of Levantinism by rebuffing the possibility of cultural bridging while simultaneously presenting characters who have no other choice but to take on the position of hybridity that her Levantine values espoused.

Concurrently, Kashua plays with the perceived Palestinian engagement with house, home and homeland. The 'Palestinian house', particularly in the framework of the village, becomes "a unifying spatial metaphor to help cope with and resist the loss of homeland". The discourse of home and homeland that had characterised Jewish notions of Levantinism, like those of identity, 
have now been inverted and reclaimed by an Arab writer. Multiple dimensions of layering are enacted though his novels in a frenzied dance whereby Arab space and historical claims are juxtaposed as Kashua's devastatingly satirises this idealisation of place. "Kashua's house is not reconstructed out of the fragments of a sometimes unreliable and idealizing memory. Instead, the description is firmly rooted in the present moment, transforming traces of the past and hints of the future into kitsch." (Grumberg 139)

Kashua's characters, and the personae of himself that he adopts in his journalistic writings, remain unable to participate in the discourse of the exilic past and the European (and Western) directional orientation of Israeli national culture. But they are also unable to participate in Palestinian national culture "since its central components are memory, yearning, and the dream of return - to the land where Israeli Palestinians still live". Unable to participate in either narrative they become the ultimate Levantine, rooted and homeless, fluid and static, ascribed identity and constantly escaping it. Intriguingly the utter disempowerment of the Palestinian Israeli, which forms his Levantiniut, is in marked contrast to the confused upper-class Mizrachi Levantine of Kahanoff's imagination.

Yet even this fixed notion is brought into question within Ronit Matalon's fiction. Her novel The One Facing Us, directly questions Kahanoff's Levantine aristocratic positioning which engages with a simultaneous "identification and disidentification with both the East and the West, colonized and colonizer"'(214) This complication is further heightened in the challenge to home and rootlessness which had characterised earlier discussion of Levantiniut, which was to be disrupted by having a homeland. Instead Matalon's characters experience a constant movement. This unsettled migration disturbs the expectations of rootedness, but movement too becomes a kind of paralysis and not a redemption: "The liminal intercultural space [the Levantines] inhabit affords them the freedom to wander but also traps them in perpetual movement, which itself becomes a kind of stasis" (214). To reach place and home, outside of the nationalist discourse is to interrupt singularity, and this too becomes a form of Levantinism. The act of disruption and the use of what Grumberg describes as a "subversive spatiality" reconfigures Levantine ideas of colonialism, migration and cultural imperialism in Africa, to provide a critique of the same experiences within Israel both for Mizrachi Jews and Arabs. "Stepping outside Matalon's narrative and considering the African shantytown in the broader Israeli cultural context within which the author and the narrator are situated, the reader may recognise... the slums of south Tel Aviv and the geographically and culturally marginal development towns, both of which are predominantly Mizrahi, or the Palestinian refugee camps in the Occupied territories" (Grumberg 243) This resonance is part of the breakdown that Matalon sets up for the "illusory unity of national and historical narrative." As Grumberg explains "characters move from place to place ... from one continent to another, from one language to another, from the past to the present." (Grumberg 246.) It is these movements that are the essence of contemporary Levantinism.

Grumberg and Horowitz demonstrate that the Israeli remains both inside and outside of space. The fluidity of Israel's boundaries, and the attempt to control them through checkpoints and barriers, are a physical manifestation of the cultural controls that the state has been attempting dating back to the earliest Zionist ideals. The Mizrachi, through increasing power, has overcome attempts of colonialisation by an Ashkenazi elite, due to attitude changes in the wider world (as Nocke claims), due to hybridisation of Mizrachi culture (as Horowitz demonstrates), and through a perceived whitening under the guise of Mediterraneanism. Using this power, the Mizrachi has 
questioned the established status quo, fragmenting narratives, places and languages. These models then suggest new and permanent frameworks, but even as they are created they become instantly interrupted through the inclusion of the Arab (as native culture, as Israeli, or as Palestinian). Levantinism disturbs attempts to contain, partly through the acts of border-crossing, linguistic calisthenics, and cultural interference that manifest within Israeli art, culture and society, but more dramatically and significantly, Levantinism in an Israeli context becomes the very act of disruption itself. 